\title{
PROBLEMATIC INTERNET USE PADA REMAJA PENGGUNA FACEBOOK DI JAKARTA BARAT
}

\author{
Esther Widhi Andangsari; Rani Agias Fitri \\ Psychology Department, Faculty of Humanities, BINUS University \\ Jln. Kemanggisan Ilir III No.45, Kemanggisan - Palmerah, Jakarta 11480 \\ esther@binus.edu; rfitri@binus.edu
}

\begin{abstract}
Paper discusses about problematic internet use on teenagers as Facebook users in West Jakarta. The objective of this study is to have empirical evidence about problematic internet use condition among teenagers as Facebook users in West Jakarta. This research is a descriptive study. Sample of this study was 82 high school students in West Jakarta. They were given GPIUS2 questionnaire constructed by Caplan. Result of the study is most of the teenagers have low score on problematic internet use especially in Facebook usage. The result is supported by the passiveness of Facebook online activity among the teenagers. However, there was a positive significant correlation between problematic internet use (PIU) and teenagers' feeling when their smartphone was left behind at home. It means they could not access their Facebook account for some time. This result is important for parents and educators to consider, given that Facebook has both positive and negative effect for teenagers.
\end{abstract}

Keywords: problematic internet use (PIU), Facebook, teenagers

\begin{abstract}
ABSTRAK
Penelitian membahas tentang persoalan penggunaan internet yang ditunjukkan lewat penggunaan Facebook oleh para remaja di Jakarta Barat. Penelitian bertujuan untuk memberikan bukti empiris mengenai taraf persoalan penggunaan Facebook di kalangan para remaja di Jakarta Barat. Penelitian merupakan studi deskriptif terhadap 82 remaja SMA di Jakarta Barat. Para responden dalam penelitian diukur dengan menggunakan alat ukur GPIUS2 yang dikembangkan oleh Caplan. Hasil menunjukkan bahwa mayoritas remaja memiliki persoalan penggunaan internet, dalam hal ini penggunaan Facebook, yang tergolong rendah. Hal ini juga ditunjukkan lewat penggunaan Facebook mereka yang tergolong kurang aktif. Akan tetapi, penelitian menunjukkan bahwa ada kaitan antara persoalan penggunaan internet, dalam hal ini penggunaan Facebook, dengan perasaan remaja jika smartphone yang digunakan untuk mengakses akun Facebook, tertinggal di rumah. Hasil ini penting untuk dicermati oleh para orangtua dan pendidik, mengingat Facebook memiliki dampak positif dan juga negatif bagi para remaja.
\end{abstract}

Kata kunci: problematic internet use (PIU), Facebook, remaja 


\section{PENDAHULUAN}

Tidak dapat dipungkiri bahwa remaja generasi saat ini yang dianggap sebagai generasi digital native, tentunya sangat akrab dengan penggunaan teknologi untuk berkomunikasi. Hadirnya telepon cerdas (smartphone) yang memiliki fitur canggih penunjang komunikasi teknologi berbasis internet, makin mempermudah remaja untuk berinteraksi dengan orang lain. Remaja saat ini terlahir untuk mahir menggunakan internet dalam segala aktivitasnya baik untuk studi maupun untuk waktu luangnya. Sementara bagi dunia orang dewasa, perlu untuk membiasakan diri menggunakan internet pada aktivitas seseharinya (Amichai-Hamburger, 2013). Kala internet mulai marak masuk dalam dunia remaja, banyak orang yang mengkhawatirkan dampak negatif bagi mereka sehingga banyak penelitian yang membahas tentang hal itu. Namun seiring dengan berjalannya waktu, makin diakui bahwa internet dinilai mempermudah interaksi antarsesama, arah penelitian juga membahas mengenai hal positif internet bagi remaja. Apalagi fungsi digital ini juga dianggap memberikan dukungan bagi remaja yang memang sangat erat dengan internet (Amichai-Hamburger, 2013).

Tahapan perkembangan remaja merupakan tahapan yang banyak berinteraksi dengan kelompok pertemanan atau peer group (Lahey, 2009). Ada perubahan yang cukup drastis dari masa kanak-kanak, yang tadinya mereka lebih banyak berinteraksi dengan keluarga, kemudian beralih lebih banyak menghabiskan waktu dengan kelompok pertemanan daripada dengan orangtua (Santrock, 1998 dalam Lahey, 2009). Tentunya tidaklah mengherankan jika situs jejaring sosial semacam Facebook digandrungi oleh remaja karena dianggap mempermudah kebutuhan mereka untuk bisa berinteraksi dengan teman-teman. Seperti dalam penelitian yang dilakukan di Belanda, diketahui bahwa hampir semua remaja di sana, yaitu sekitar $80 \%$ remaja Belanda menggunakan internet untuk melakukan komunikasi interpersonal (Valkenburg \& Peter, 2007, dalam van den Eijnden, Meerkerk, Vermulst, Spijkerman, \& Engels, 2008).

Pengguna Facebook di Indonesia, khususnya para remaja Indonesia, dari 1,9 miliar akun Facebook yang ada di dunia, Indonesia menduduki peringkat keempat terbesar di dunia. Data pada 2013 menyebutkan bahwa Indonesia memiliki sebanyak 65 juta pengguna aktif Facebook (Susanto, 2013). Berdasarkan kelompok usia, dari 65 juta pengguna Facebook tersebut kelompok usia terbanyak pengguna Facebook di Indonesia berada pada usia 18-24 tahun sebesar 43,7\%. Kelompok usia terbanyak kedua yaitu berada pada usia 25-34 tahun sebesar 23,4\%, disusul dengan kelompok usia 617 tahun sebesar 12,5\% (Socialbakers, 2013). Artinya dari dua kelompok usia tersebut, pengguna Facebook kategori remaja antara usia 12-18 tahun cukup besar. Hal ini sejalan dengan pandangan pakar yang menyatakan bahwa penggunaan internet sangat umum di kalangan remaja, apalagi dianggap mendukung kebutuhan mereka untuk menjalin komunikasi interpersonal.

Penggunaan Facebook yang makin marak di kalangan orang muda atau remaja, tidak hanya di Indonesia tetapi juga dunia, tentunya menjadi daya tarik juga bagi para peneliti. Banyak penelitian yang terus menelurusi mengenai keterkaitan penggunaan internet atau Facebook dengan kehidupan penggunanya. Facebook dapat begitu digemari oleh orang muda, salah satu jawabannya adalah bahwa Facebook dianggap sebagai salah satu alternatif komunikasi interpersonal yang modern. Tidak heran di kalangan orang muda penggunaan surat elektronik (email) makin menurun (Hargittai, 2008, dalam Anderson, Woodnutt, Fagan, Chamorro-Premuzic, 2012).

Namun dari aneka penelitian yang ada, penelitian mengenai kaitan Facebook dengan penggunanya tidak lagi berat sebelah. Cukup ada keseimbangan arah penelitian yang membahas antara dampak negatif dan juga positif dari penggunaan Facebook di kalangan remaja dan mahasiswa. Dampak negatif dari penggunaan Facebook terpapar pada beberapa penelitian yang ada. Penelitian menunjukkan bahwa penggunaan Facebook menjadi indikator dari gejala yang parah dalam hal kecanduan internet meskipun hanya dialami oleh sejumlah kecil mahasiswa (Kitinger, Correia, \& 
Irons, 2012). Selain itu dari penelitian di Turki diketahui bahwa kesepian merupakan variabel yang penting dikaitkan dengan kecanduan internet (Bozoglan, Demirer, \& Sahin, 2013).

Studi jangka panjang terhadap para remaja mengenai penggunaan internet yang kompulsi, depresi, dan kesepian menunjukkan hasil bahwa ada pengaruh yang positif antara chatting online dan instant messenger dengan penggunaan internet yang kompulsif pada 6 bulan berikutnya, serta berhubungan secara positif dengan depresi, tetapi memiliki hubungan yang negatif dengan kesepian (van den Eijnden, Meerkerk, Vermulst, Spijkerman, \& Engels, 2008). Hasil penelitian tersebut berbeda dengan yang ditemukan oleh Kraut, et.al tahun 1998 dalam studi jangka panjangnya yang menyatakan bahwa penggunaan internet banyak dikaitkan dengan persoalan mengenai kesehatan mental, semisal depresi dan kesepian (Caplan, 2003; Kang, 2007). Pada bidang akademik juga diperoleh hasil penelitian yang menyatakan bahwa aktivitas internet seperti akses situs jejaring sosial memiliki hubungan positif yang signifikan dengan kecanduan internet pada remaja dengan rentang usia 9-19 tahun di Hongkong (Leung \& Lee, 2012).

Dari sekian banyak penelitian, setidaknya masih ada penelitian yang mengkaji sisi positif dari penggunaan internet terutama penggunaan Facebook. Hasil penelitian menunjukkan bahwa banyaknya jumlah teman pada akun Facebook memiliki hubungan yang positif terhadap subjective well-being (Kim \& Lee, 2011). Penelitian ini dilakukan pada 391 mahasiswa pengguna Facebook dimana diketahui lebih lanjut bahwa self-presentation yang positif memiliki dampak langsung terhadap subjective well-being. Sedangkan self-presentation yang jujur memiliki dampak yang tidak langsung terhadap subjective well-being yang dipersepsikan terhadap dukungan sosial yang diperoleh oleh mereka. Dari sekian banyak penelitian yang telah dipublikasikan, tidak banyak literatur yang memuat tentang penggunaan internet atau Facebook dan kaitannya terhadap remaja atau orang muda di Indonesia atau di Jakarta secara khusus. Bagaimana penggunaan Facebook di kalangan remaja terutama di Jakarta; apakah penggunaan Facebook pada kelompok usia tersebut berada pada kategori yang sudah mengkhawatirkan ataukah masih dalam taraf yang bisa ditoleransi; dua pertanyaan yang diajukan sebagai rumusan masalah dari penelitian ini merupakan pertanyaan yang mendasar. Pertanyaan yang jawabannya akan menentukan studi selanjutnya dan tentunya tindak lanjut dari hasil studi yang diperoleh.

Tulisan ini bertujuan untuk memberikan gambaran mengenai penggunaan internet yaitu yang ditunjukkan lewat penggunaan Facebook dikalangan remaja di Jakarta. Apakah mereka sudah menunjukkan penggunaan Facebook yang bermasalah? Artinya penggunaan Facebook mereka selama ini apakah sudah menunjukkan gejala penggunaan Facebook yang berlebihan atau masih dalam taraf yang wajar. Orang dewasa terutama orangtua dan pendidik yang berasal dari generasi digital immigrant sering kali menuding bahwa remaja atau orang muda sekarang sudah sangat gandrung dengan internet terutama terhadap penggunaan akun Facebook mereka. Dari pernyataan tersebut sebenarnya terselip segudang kekhawatiran bahwa situs jejaring sosial tersebut disanyelir lebih banyak memberikan pengaruh yang negatif daripada pengaruh yang positif. Perlu ada data empiris yang akan secara objektif memberikan data yang berguna bagi setiap orang yang merasa perlu dan ingin tahu tentang hal ini.

\section{Penggunaan Internet yang Bermasalah}

Pada penelitian ini penggunaan internet yang bermasalah atau problematic internet use (PIU) ditunjukkan dengan penggunaan Facebook di kalangan remaja di Jakarta. Konsep penggunaan internet yang bermasalah merupakan pandangan yang sedikit berbeda dengan pandangan yang menyatakan mengenai kecanduan internet (internet addiction). Pandangan terhadap penggunaan internet dari sudut pandang klinis ini diusung oleh Young yang merumuskan 8 kriteria kecanduan judi untuk diaplikasikan pada penggunaan internet (Tokunaga \& Rains, 2010; Debernardi, 2012). Kedelapan kriteria kecanduan penggunaan internet tersebut meliputi preokupasi terhadap internet, meningkatnya penggunaan waktu online untuk mencapai kepuasan, adanya usaha-usaha yang tidak berhasil untuk 
mengendalikan penggunaan internet, perasaan gelisah-depresi-suasana hati yang tak menentu saat offline, berlama-lama saat online di luar ketentuan, mengabaikan pekerjaan dan relasi lainnya demi menggunakan internet, berbohong kepada orang lain mengenai jumlah waktu yang digunakan saat online, dan menggunakan internet sebagai cara untuk melarikan diri dari masalah atau untuk menenangkan suasana hati (Young, 2004; Debernardi, 2012). Pada intinya jika penggunaan internet memunculkan ketergantungan psikologis terhadap internet, hal itu harus diperhatikan sebagai gangguan patologis.

Sementara itu pandangan non-klinis yang tidak melihat penggunaan internet sebagai sesuatu yang patologis diusung pada awalnya oleh Davis (2001, dalam Debernardi, 2012). Ia mengajukan model etiologis dari PIU berdasarkan pendekatan kognitif-perilaku. Pada konsep ini, predisposisi psikososial mengarahkan individu untuk melakukan interaksi sosial lewat internet yang berlebihan (excessive) dan kompulsif yang dapat memperburuk persoalan individu tersebut. Istilah Problematic Internet Use (PIU) sendiri digunakan untuk menunjukkan karakteristik dari perilaku dan kognisi yang maladaptif dalam penggunaan internet yang berdampak buruk pada beragam bidang termasuk akademik, kehidupan profesional, dan sosial (Caplan, 2002; Davis, 2001; Davis, Flett, \& Besser, 2002, dalam Caplan, 2010). Berdasarkan konsepsi dari Davis ini, dirumuskan karakteristik individu yang mengalami problematic internet use (PIU), yaitu: individu yang menderita persoalan psikososial seperti depresi dan kesepian; individu tersebut lebih banyak melakukan interaksi sosial secara online sebagai alternatif dari komunikasi tatap muka karena dianggap kurang mengancam; keinginannya untuk selalu interaksi secara online membuat individu tersebut memiliki persoalan interaksi sosial lewat internet yang berlebihan dan kompulsif sehingga berdampak pada bidang kehidupannya yang lain (Caplan, 2003).

Konsep ini kemudian makin disempurnakan oleh Caplan. Ia menyatakan bahwa PIU merupakan konstelasi dari pikiran, perilaku, dan keluaran lainnya ketimbang suatu gangguan atau kecanduan (Caplan \& High, 2011). Pembaruan dari konsep ini pun tercermin dari alat ukur yang dikembangkan, yaitu Generalized Problematic Internet Use (GPIU). Alat ukur ini berangkat dari konsepsi Davis yang menyatakan bahwa individu yang mengalami persoalan psikososial lebih memilih untuk melakukan interaksi sosial secara online daripada interaksi secara tatap muka (Caplan, 2003, dalam Caplan, 2010). Kemudian GPIU ini dikembangkan menjadi Generalized Problematic Internet Use Scale 2 (GPIUS2) yang menggabungkan konsepsi Davis yaitu teori perilaku-kognitif dari GPIU dan konsepsi Caplan yaitu pilihan untuk berinteraksi sosial secara online, dan model sosiokognitif dari penggunaan internet yang tidak teratur (Caplan, 2010).

Pada model GPIU perbedaan terlihat pada pemahaman bahwa persoalan psikososial yang dihadapi oleh individu dapat mengembangkan kognisi yang maladaptif yang dapat mengarahkan individu untuk sulit mengendalikan dorongan atau impuls perilaku, yang merupakan hasil dari keluaran negatif (negative outcomes) dari penggunaan internet.Terlihat jelas bahwa bagi GPIU keluaran negatif dipandang sebagai konsekuensi, bukan sebagai penyebab (Caplan, 2010). Sehingga hal tersebut akan memunculkan pilihan untuk berinteraksi secara online, mood alteration, preokupasi kognitif, dan perilaku kompulsi. Sementara GPIUS2 memasukkan dua faktor baru yaitu preference for online social interaction (POSI) dan pengurangan pengaturan diri (Caplan, 2010). Dengan demikian domain dari GPIUS2 terdiri atas POSI, mood regulation, preokupasi kognisi, penggunaan internet yang kompulsi, dan keluaran negatif.

\section{METODE}

Penelitian ini merupakan penelitian kuantitatif dengan melihat pada tinjauan deskriptif. Responden dalam penelitian ini adalah pelajar SMA kelas 10-12, berusia antara 15-19 tahun yang bersekolah di daerah Jakarta Barat, dan memiliki akun Facebook. Jakarta Barat dipilih sebagai 
pertimbangan kemudahan pelaksanaan studi yang dekat dengan lokasi kampus peneliti. Peneliti mendatangi beberapa sekolah yang ada di Jakarta Barat untuk meminta kerja sama pihak sekolah agar memberikan izin bagi peneliti untuk mengambil data guna keperluan penelitian. Total responden dalam penelitian ini adalah 82 orang. Mereka diberikan kuesioner GPIUS2 yang dikembangkan oleh Caplan, yang terlebih dulu diadaptasi oleh peneliti lewat metode translasi forward-backward. Dalam proses adaptasi alat ukur ini, peneliti memutuskan untuk mengganti kata "internet" pada setiap item dengan kata "Facebook". Hal ini dilakukan mengingat tujuan penelitian yang ingin mendapatkan gambaran mengenai penggunaan internet yang bermasalah yang ditunjukkan oleh penggunaan Facebook. Sehingga pergantian kata tersebut dinilai akan memudahkan fokus responden dalam mengisi kuesioner.

Alat ukur GPIUS2 terdiri atas 15 item dan diadaptasi oleh peneliti dalam empat skala Likert, yaitu "sangat tidak setuju", "tidak setuju", "setuju", dan "sangat setuju". Responden diminta untuk memilih satu dari empat pilihan jawaban pada setiap item berdasarkan kenyataan yang mereka rasakan saat menggunakan Facebook. Hasil uji coba alat ukur adaptasi peneliti ini memperoleh besaran keseluruhan konsistensi internal sebesar $\alpha=850$. Hasil ini tidak jauh berbeda dengan konsistensi internal dari Caplan sendiri yaitu sebesar $\alpha=.91$ (Caplan, 2010). Hanya saja masih ada perbedaan konsistensi internal untuk kelima domain GPIUS2 yang berada pada rentang antara $\alpha=.424$ hingga $\alpha=.557$. Hasil ini masih sangat berbeda jauh dengan yang dihasilkan sendiri oleh Caplan yaitu antara $\alpha=.82$ hingga $\alpha=.87$ (Caplan, 2010).

\section{HASIL DAN PEMBAHASAN}

Dari 82 pelajar SMA di Jakarta Barat yang menjadi responden, jumlah responden laki-laki $=$ 45 orang $(54.88 \%)$ dan responden perempuan $=37$ orang $(45.12 \%)$. Gambaran mengenai rentang usia responden dapat dilihat pada Tabel 1 berikut.

Tabel 1 Rentang Usia Responden

\begin{tabular}{ccr}
\hline Usia & $\mathbf{N}$ & \multicolumn{1}{c}{$\%$} \\
\hline 15 tahun & 12 & 14.63 \\
16 tahun & 14 & 17.07 \\
17 tahun & 47 & 57.32 \\
18 tahun & 6 & 7.32 \\
19 tahun & 3 & 3.66 \\
Total & 82 & 100.00 \\
\hline \multicolumn{2}{c}{ Sumber: }
\end{tabular}

Dari data pada Tabel 1 dapat terlihat bahwa kelompok usia responden terbesar berada pada kelompok usia 17 tahun (mean=16.68). Jika dikaitkan dengan waktu pertama kali mereka memiliki akun Facebook, dapat dilihat sebagai berikut. 
Tabel 2 Tahun Memiliki Akun Facebook

\begin{tabular}{lcr}
\hline Tahun & n & \multicolumn{1}{c}{ \% } \\
\hline 2006 & 3 & 3.66 \\
2007 & 3 & 3.66 \\
2008 & 33 & 40.24 \\
2009 & 27 & 32.93 \\
2010 & 8 & 9.76 \\
2011 & 2 & 2.44 \\
2012 & 3 & 3.66 \\
2013 & 1 & 1.22 \\
missing & 2 & 2.44 \\
Total & 82 & 100.00 \\
\hline
\end{tabular}

Sumber: Data penelitian 2013

Dengan demikian dapat diartikan bahwa kebanyakan dari responden sudah memiliki akun Facebook sejak 4-5 tahun lalu, yaitu ketika mereka masih berusia sekitar 12-13 tahun. Para responden sudah memiliki akun Facebook saat mereka masih duduk di bangku sekolah dasar tingkat akhir dan tingkat SMP awal.

Usia 12-13 tahun merupakan usia remaja awal yang baru puber, yang tentunya sangat menikmati interaksi dengan kelompok pertemanan setelah biasanya mereka lebih banyak berinteraksi dengan orang tua (Santrock, 1998, dalam Lahey, 2009). Ini berarti bahwa anak-anak generasi digital native memang sangat menggemari teknologi yang bersifat interaktif berbasis internet. Apalagi pada 2008-2009 Facebook kala itu cukup tenar di Indonesia dan dunia, setelah kemunculannya di Amerika Serikat tahun 2004.

Hasil pengukuran melalui alat ukur GPIUS2 diperoleh hasil seperti pada Tabel 3 berikut.

Tabel 3 Skor GPIUS2

\begin{tabular}{lr}
\hline Minimum & 9 \\
Maksimum & 31 \\
Mean & 17.33 \\
\hline
\end{tabular}

Sumber: Data penelitian 2013

Tabel 4 Kategori Kelompok Skor

\begin{tabular}{lcr} 
Kategori & $\mathbf{N}$ & \multicolumn{1}{c}{ \% } \\
\hline Rendah & 43 & 52.44 \\
Tinggi & 39 & 47.56 \\
Total & 82 & 100.00 \\
\hline
\end{tabular}

Sumber: Data penelitian 2013

Dengan mean sebesar 17.33, pembagian kelompok skor berdasarkan mean kelompok tersebut seperti yang tertera pada Tabel 4. Dari Tabel 4 dapat disimpulkan bahwa kelompok responden terbanyak berada pada kategori skor GPIUS2 yang tergolong rendah berdasarkan mean kelompok penelitian. Artinya para responden memiliki penggunaan internet bermasalah, dalam hal ini, penggunaan Facebook yang masih tergolong rendah. Mereka masih menunjukkan pada batasan yang wajar mengenai karakteristik kompulsif kognitif terhadap Facebook. Artinya, para responden tidak memiliki pemikiran untuk selalu online Facebook walaupun mereka sudah tidak online lagi. Para responden juga tidak menunjukkan perilaku penggunaan Facebook yang kompulsif, serta belum 
terlihat luaran perilaku yang negatif, yaitu berupa persoalan sosial dalam kehidupannya akibat penggunaan Facebook yang berlebihan dan kompulsif.

Namun pada Tabel 4 terdapat sejumlah 47,56\% dari responden yang menunjukkan karakteristik sebaliknya. Karakteristik secara kognitif dan perilaku akibat penggunaan Facebook yang berlebihan dan kompulsif. Mereka ini selalu menginginkan Facebook tetap online walaupun sudah offline, penggunaan Facebook sudah menunjukkan perilaku yang kompulsif, serta mengalami persoalan sosial dalam hidup akibat penggunaan Facebook yang berlebihan dan kompulsif. Tentunya, mereka membutuhkan perhatian dan penanganan yang khusus.

Masih cukup besarnya persentase responden yang berada pada kelompok skor rendah dari GPIUS2 membuat peneliti perlu untuk menggali aktivitas online Facebook para responden. Apakah mereka sebenarnya adalah pengguna Facebook yang aktif atau justru hanyalah pengguna Facebook yang pasif. Pada penelitian ini responden diminta untuk mengisi beberapa item yang terkait dengan aktivitas online Facebook dengan menentukan hal yang sebenarnya terjadi berdasarkan skala Likert yang menunjukkan frekuensi. Mereka dapat mengisi dengan pilihan jawaban "tidak pernah sama sekali", "jarang/kadang-kadang", "sering", "sangat sering". Peneliti mengelompokkan pilihan jawaban "tidak pernah sama sekali" dan "jarang/kadang-kadang" sebagai bentuk perilaku tidak aktif dalam online Facebook.Sementara pilihan jawaban "sering" dan "sangat sering" dikategorikan sebagai bentuk perilaku aktif dalam online Facebook.

Berikut ini hasil dari pengukuran mengenai aktivitas online Facebook para responden.

Tabel 5 Aktivitas Online Facebook

\begin{tabular}{lcc}
\hline \multicolumn{1}{c}{ Upload foto atau video } & N & $\mathbf{\%}$ \\
\hline Aktif & 26 & 31.71 \\
Tidak Aktif & 56 & 68.29 \\
& & \\
Menuliskan status atau merubah status & & \\
Aktif & 27 & 32.93 \\
Tidak Aktif & 55 & 67.07 \\
& & \\
Menuliskan komentar atau membalas komentar orang lain & & \\
Aktif & 38 & 46.34 \\
Tidak Aktif & 44 & 53.66 \\
& & \\
Menuliskan atau share tautan/link & & \\
Aktif & 19 & 23.17 \\
Tidak Aktif & 63 & 76.83 \\
\hline
\end{tabular}

Sumber: Data Penelitian 2013

Data pada Tabel 5 makin memperkuat ciri atau karakteristik remaja yang memang senang ikut trend, dimana memiliki akun Facebook merupakan semacam trend tersendiri. Namun pada dasarnya kelompok remaja pada penelitian ini bukanlah pengguna aktif Facebook. Aktivitas yang cukup banyak dilakukan oleh responden saat online Facebook adalah menuliskan komentar atau membalas komentar orang lain $(46.34 \%)$. Hal ini merupakan aktivitas yang bagi remaja merupakan aktivitas untuk bisa berinteraksi dengan orang lain layaknya interaksi sosial tatap muka. Banyaknya responden yang tidak aktif atau pasif dalam online Facebook dapat dikategorikan sebagai passive social browsing dalam menggunakan Facebook yang diusung oleh Wise, Alhabash, and Park tahun 2010 (Anderson, Woodnutt, Fagan, \& Chamorro-Premuzic, 2012). Lebih lanjut dipaparkan pada tulisan tersebut bahwa passive social browsing dalam penggunaan Facebook merupakan orang-orang yang memiliki akun Facebook namun dalam aktivitas online mereka lebih banyak hanya membaca status atau komentar 
orang lain, melihat-lihat foto atau video orang lain, dan sebagainya. Pada dasarnya mereka lebih banyak untuk sekadar observasi Facebook.

Selain itu peneliti juga melihat adanya fenomena penggunaan telepon cerdas (smartphone) untuk akses Facebook. Sehingga peneliti juga menanyakan tentang perasaan mereka jika pada saat sedang bepergian, telepon genggam mereka tertinggal di rumah. Pertanyaan ini bertujuan untuk mendapatkan gambaran mengenai perasaan mereka karena pada saat itu berarti para responden selama beberapa waktu tertentu tidak dapat akses akun Facebook mereka atau terkoneksi dengan orang lain. Mereka dapat memilih hanya satu jawaban dari pilihan jawaban "sangat panik/sangat cemas", "panik/bingung", "sedikit panik/bingung", dan "biasa saja". Tabel 6 merupakan hasil dari pengukuran tersebut.

Tabel 6 Perasaan Jika Smartphone Tertinggal di Rumah

\begin{tabular}{lcc}
\hline \multicolumn{1}{c}{ Perasaan responden } & N & \% \\
\hline Sangat panik/Sangat Cemas & 13 & 15.85 \\
Panik/Bingung & 17 & 20.73 \\
Sedikit panik/bingung & 30 & 36.59 \\
Biasa saja & 22 & 26.83 \\
Total & 82 & 100.00 \\
\hline
\end{tabular}

Sumber: Data Penelitian 2013

Hasil menunjukkan bahwa lebih banyak responden merasa sedikit panik/bingung (36.59\%). Cukup banyak yang merasa biasa saja (26.83\%), tetapi ada sekitar $20.73 \%$ dari total responden yang merasa panik/bingung jika smartphone mereka tertinggal di rumah. Jika dikorelasikan antara skor GPIUS2 para responden dengan perasaan mengenai smartphone ini, ada hubungan positif yang signifikan antara skor GPIUS2 dengan perasaan mengenai smartphone yang tertinggal di rumah $(\mathrm{r}=.304, \mathrm{p}<.01)$ walaupun besaran korelasi tersebut tidak terlalu kuat. Sehingga dapat diartikan bahwa makin meningkatnya persoalan penggunaan internet pada Facebook, maka para remaja akan makin merasa panik/cemas jika smartphone mereka tertinggal di rumah. Demikian pula sebaliknya, remaja makin merasa panik/cemas jika smartphone mereka tertinggal di rumah, itu menjadi indikasi bahwa mereka memiliki persoalan penggunaan internet pada Facebook yang tinggi pula.

\section{SIMPULAN}

Dugaan bahwa remaja sudah dikategorikan sebagai individu yang memiliki persoalan penggunaan internet, dalam hal ini penggunaan Facebook, tidak terbukti secara empiris. Dari data penelitian terlihat bahwa mayoritas remaja di Jakarta Barat masih berada pada kategori rendah dalam hal persoalan penggunaan Facebook mereka.Walaupun demikian, para orangtua dan pendidik tidak bisa menutup mata bahwa ada sejumlah besar remaja di Jakarta Barat yang sudah berada pada kategori memiliki persoalan dalam penggunaan Facebook. Penggunaan Facebook oleh para remaja di Jakarta Barat dapat dikatakan belum berlebihan dan kompulsif berdasarkan konsepsi yang diusung oleh Caplan $(2003 ; 2010)$. Tentunya hal ini memunculkan pertanyaan bagaimana bisa remaja tersebut tidak memiliki persoalan dalam penggunaan Facebook mereka. Hal ini dapat dijelaskan lewat aktivitas online Facebook para remaja. Walaupun mereka mengikuti tren kepemilikan akun Facebook bahkan sejak usia yang cukup dini, kebanyakan dari mereka ternyata adalah pengguna pasif Facebook (passive social browsing) (lihat data pada Tabel 5).

Hasil ini merupakan sesuatu yang menarik karena walaupun mereka memiliki fasilitas gadget untuk dapat akses Facebook, para remaja ini dengan segala tren yang ada dan fasilitas yang tersedia 
hanyalah merupakan observer dari Facebook. Meskipun begitu, hal ini juga dapat memunculkan dugaan bahwa karakteristik remaja yang labil ini, terutama dalam emosi, dapat membuat mereka mudah mengikuti tren. Sebenarnya mereka dapat memanfaatkan hal yang positif dari penggunaan Facebook, seperti interaksi sosial dengan kelompok pertemanan dan bahkan mendapatkan dukungan sosial dari temannya atau orang lain secara online (Kim \& Lee, 2011). Artinya mereka perlu diajarkan untuk mengkaji suatu fasilitas atau aplikasi teknologi, yang sebetulnya pada batas yang bisa dikendalikan, dapat memberikan manfaat positif bagi diri mereka. Terkait dengan dugaan remaja hanya sekadar mengikuti tren dalam penggunaan Facebook dan sebagainya, memang masih perlu untuk ditelusuri lebih lanjut dalam penelitian yang sejenis. Penelitian ini dapat menjadi data awal untuk meneliti mengenai perilaku menggunakan situs jejaring sosial dari para remaja di Jakarta.

Meskipun banyak di antara remaja di Jakarta Barat ini tidak masuk dalam kelompok individu yang tidak mengalami persoalan penggunaan internet, dalam hal ini penggunaan Facebook, bukan berarti para orangtua dan pendidik lengah untuk terus memerhatikan penggunaan Facebook dan juga smartphone. Hasil penelitian yang memaparkan bahwa ada korelasi positif yang signifikan antara perasaan mereka jika smartphone mereka tertinggal di rumah dengan skor GPIUS2 mereka menunjukkan bahwa mereka melekatkan diri dengan alat komunikasi tersebut. Orangtua dan pendidik harus mencermati bahwa ada indikasi terjadinya persoalan penggunaan Facebook yang berlebihan dan kompulsif jika remaja makin merasa panik atau cemas ketika smartphone tidak mereka bawa. Ada kebutuhan untuk selalu ingin menggunakan internet atau Facebook. Peneliti menduga bahwa sesungguhnya para remaja mungkin secara perilaku tidak terlihat bentuk kompulsif terhadap interaksi online Facebook. Namun secara kompulsif pada area kognitif ada kemungkinan mereka ingin selalu online walaupun sesungguhnya mereka sedang offline (Caplan, 2003). Untuk itu perlu dilakukan studi berikutnya mengenai pengukuran problematic internet use dalam kaitannya dengan penggunaan Facebook melalui analisis PIU pada setiap domainnya, diawali dengan penyusunan alat ukur sejenis GPIUS2 yang disesuaikan dengan karakteristik remaja Indonesia. Alat ukur GPIUS2 hasil adaptasi peneliti dalam penelitian ini masih belum memadai dalam hal reliabilitas pada kelima domain.

Studi ini memiliki keterbatasan dalam hal besaran sampel penelitian. Penelitian ini hanya membahas remaja di Jakarta Barat dengan jumlah sampel yang masih minim. Sehingga penelitian yang sejenis perlu dilakukan dengan jumlah sampel yang lebih besar dan mewakili wilayah-wilayah yang ada di Jakarta. Selain itu studi ini merupakan studi deskriptif yang perlu ditindaklanjuti dalam studi yang lebih jauh lagi. Perlu untuk diteliti kaitan antara persoalan penggunaan internet yang ditunjukkan lewat penggunaan Facebook dengan variabel lain yang terkait dengan kesehatan mental serta kualitas hidup remaja. Seperti depresi, kesepian, dan juga subjective well-being atau psychological well-being.

\section{DAFTAR PUSTAKA}

Amichai-Hamburger, Y. (2013). Youth internet and well-being. Computers in Human Behavior, 29, $1-2$.

Anderson, B., Woodnutt, T., Fagan, P., \& Chamorro-Premuzic, T. (2012). Facebook Psychology: Popular Questions Answered by Research. Psychology of Popular Media Culture, 1(1), 23-37.

Bozoglan, B., Demirer, V., \& Sahin, I. (2013). Loneliness, self-esteem, and life satisfaction as predictors of Internet. Scandinavian Journal of Psychology, 54, 313-319.

Caplan, S. E. (2003). Preference for Online Social Interaction. A Theory of Problematic Internet Use and Psychosocial Well-Being. Communication Research, 30(6), 625-648. 
Caplan, S. E. (2010). Theory and measurement of generalized problematic Internet use: A two-step approach. Computers in Human Behavior, 26, 1089-1097.

Caplan, S., \& High, A. (2011). Online Social Interaction, Psychosocial Well-Being, and Problematic Internet Use. In K. Young, \& C. de Abreu, Internet Addiction. A Handbook and Guide to Evaluation and Treatment (pp. 35-53). New Jersey: John Willey \& Sons.

Debernardi. (2012). Problematic Internet Use: Exploring The Roles of Attachment and Social Competency. Missouri: ProQuest LLC.

Kang, S. (2007). Disembodiment in Online Social Interaction: Impact of Online Chat on Social Support and Psychosocial Well-Being. CyberPsychology \& Behavior, 10(3), 475-477.

Kim, J., \& Lee, J.-E. R. (2011). The Facebook Paths to Happiness: Effects of the Number of Facebook Friends and Self-Presentation on Subjective Well-Being. CYBERPSYCHOLOGY, BEHAVIOR, AND SOCIAL NETWORKING, 14(6).

Kitinger, R., Correia, C., \& Irons, J. (2012). Relationship Between Facebook Use and Problematic. CYBERPSYCHOLOGY, BEHAVIOR, AND SOCIAL NETWORKING, 15(6), 324-327.

Lahey, B. B. (2009). Psychology: An Introduction (10th ed.). New York: McGraw-Hill.

Leung, L., \& Lee, P. S. (2012). Impact of Internet Literacy, Internet Addiction Symptoms, and Internet Activities on Academic Performance. Social Science Computer Review, 30(4), 403-418.

Socialbakers. (2013). Indonesia Facebook Statistic. Diakses 20 Desember 2013 dari Socialbakers: http://www.socialbakers.com/facebook-statistics/indonesia

Susanto, D. (2013, September 23). Diakses 20 Desember 2013 dari Merdeka.com: http://www.merdeka.com/teknologi/data-terkini-pengguna-facebook-di-indonesia

Tokunaga, R., \& Rains, S. (2010). An Evaluation of Two Characterizations of The Relationships Between Problematic Internet Use, Time Spent Using the Internet, and Psychosocial Problems. Human Commmunication Research, 36, 512-545.

Van den Eijnden, R. J., Meerkerk, G.-J., Vermulst, A., Spijkerman, R., \& Engels, R. (2008). Online Communication, Compulsive Internet Use, and Psychosocial Well-. Developmental Psychology, 44(3), 655-665.

Young, K. (2004). Internet Addiction.A New Clinical Phenomenon and Its Consequences. The American Behavioral Scientist, 48(4), 402-415. 